\title{
Pharmacognostical Studies on Acer campestre L. subsp. campestre
}

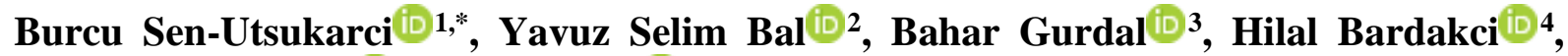 Fatima Nur Yilmaz ${ }^{(D)}$, Sibel Dosler ${ }^{(D)}$}

\author{
${ }^{1}$ Department of Pharmacognosy, Faculty of Pharmacy, Istanbul University, Istanbul, Turkey \\ ${ }^{2}$ Faculty of Pharmacy, Istanbul University, Istanbul, Turkey \\ ${ }^{3}$ Department of Pharmaceutical Botany, Faculty of Pharmacy, Istanbul University, Istanbul, Turkey \\ ${ }^{4}$ Department of Pharmacognosy, Faculty of Pharmacy, Acibadem Mehmet Ali Aydinlar University, Istanbul, \\ Turkey \\ ${ }^{5}$ Department of Pharmaceutical Microbiology, Faculty of Pharmacy, Istanbul University, Istanbul, Turkey
}

\begin{abstract}
This study on Acer campestre L. subsp. campestre, used traditionally in treatments of various inflammation disorders, especially hemorrhoids and rheumatism, aimed to determine the total phenolic contents, the antioxidant and antimicrobial potentials, and the chemical composition profile of the extracts and subextracts from maple syrup and Acer campestre L. subsp. campestre leaves and twigs. The antioxidant activities of maple syrup extracts and subextracts were examined by 2,2-diphenyl-1-picryl-hydrazyl (DPPH), and the total phenolic contents of all samples were determined using the Folin-Ciocalteu reagent (FCR) method. Also, they were tested for their antimicrobial activities by microbroth dilution technique. Catechic tannin, saponins and flavonoids are determined in its leaves and twigs by preliminary qualitative phytochemical analysis. The alcoholic extracts obtained by 48-hour maceration (91.2\%), ethyl acetate subextract of alcohol extracts obtained by 24-hour maceration $(91.1 \%$ ) and alcohol extracts obtained by 24 -hour maceration (88.8\%) exhibited higher radical scavenging activity than other samples, while the decoction and infusion had moderate activities. Beside of this, it was found that the syrup and its subextracts have more total phenolic contents than other extracts. The alcohol extracts obtained by 24-hour maceration and by 48-hour maceration exhibited higher activity against Candida albicans $(78 \mu \mathrm{g} / \mathrm{mL}$ and $156 \mu \mathrm{g} / \mathrm{mL}$, respectively). Only the alcohol extract obtained by 48 -hour maceration and ethyl acetate subextract of syrup showed an activity against Escherichia coli, while all samples except butanol subextract of syrup have an antibacterial activity against Pseudomonas aeruginosa.
\end{abstract}

\section{ARTICLE HISTORY}

Received: March 31, 2020

Revised: April 27, 2020

Accepted: May 13, 2020

\section{KEYWORDS}

Acer campestre subsp.

campestre,

Maple syrup,

Antioxidant,

Total phenolic content,

Antimicrobial

\section{INTRODUCTION}

Oxygen-derived free radicals have a major role in the development of oxidative stress and may cause various chronic and degenerative diseases such as coronary heart disease, stroke, inflammatory diseases, aging, cancer and diabetes mellitus. In addition to these, the role of these radicals in the inflammatory process was already proved and it was specified that they are

CONTACT: Burcu Sen-Utsukarci $₫$ burcusen@istanbul.edu.tr Đ Department of Pharmacognosy, Faculty of Pharmacy, Istanbul University, Istanbul, Turkey 
implicated in the activation of nuclear factor $\mathrm{kB}$, which induces the transcription of inflammatory cytokines and cyclo-oxygenase 2 . The antioxidant agents scavenge or increase the effects of these radicals and play therefore an important role to prevent and also to treat the diseases that are caused by oxidative stress. In recent years, natural antioxidant compounds come into prominence in many investigations because of the unfavorable effects of synthetic antioxidants. Many studies on the contribution of phenolic compounds to antioxidant activities of plants exist in literature [1,2]. It is well known that these compounds exhibit also good antiinflammatory activity [3,4]. This relationship between antioxidant and anti-inflammatory properties are subject to an increasing number of studies. As a matter of fact, it was designated with the recent studies on anti-inflammatory plants that their anti-inflammatory activity is related to the synergistic effects of free radical scavenging activities, effects like corticoid or pro-inflammatory enzyme inhibitors $[1,2]$.

Maple syrup, used in food industry as a sweetener, is prepared from various Acer species and is mostly produced in eastern North America, Canada and the United States, with the province of Quebec (in Canada) responsible for the majority of the world's supply (approximately 80\%) [5]. Many investigations on maple syrup exist in literature [6-19]. Apart from the content of maple syrup such as amino acids (arginine, threonine, proline, etc.), vitamins (riboflavin, niacin, thiamine, etc.), minerals ( $\mathrm{K}, \mathrm{Ca}, \mathrm{Mg}, \mathrm{Na}, \mathrm{Mn}, \mathrm{Al}, \mathrm{Zn}, \mathrm{Fe}$, etc.), phytohormones (abscisic acid and phaseic acid and their metabolites) and organic acids (fumaric acid, malic acid, etc.) [6-8], the phenolic compounds (belonging to lignan, phenolic acid, stilbene, coumarin and flavonoid subclasses) are secondary metabolites, mostly isolated from the syrup [9-14]. The anticancer, antioxidant, $\alpha$-glucosidase enzyme inhibitory, and antiinflammatory activities were determined in previous in vitro studies [15-17] as well as liverprotective effects in animal studies [18] and the potential to reduce plasma glucose levels [19]. Some of the studies on maple syrup and Acer species is mostly used in the production of maple syrup (A. saccharum Marsh., A. rubrum L.) are very interesting and useful. The mechanism of action of the anti-inflammatory effect was studied, and its potency was displayed by comparing resveratrol, curcumin and quercetin, which are known as strong anti-inflammatory compounds [17]. The antioxidant, antiradical and antimutagenic activities of the phenolic compounds in the syrup were also investigated and it was found that all the studied phenolic compounds showed antioxidant and antiradical activity and the glycosylated phenolic compounds were more effective than the aglycons [20].

In a study on cytotoxicity of maplexins A-I from Acer rubrum L., it was shown that the two (maplexins C-D) or three (maplexins E-I) galloyl derivatives had antiproliferative effects against HCT-116 and MCF-7 cells, and the cancer cells were up to 2.5-fold more sensitive to the maplexins than the normal cells [21]. In an investigation on the anti-hyperglycemic activity of the methanol extract prepared from Acer saccharum Marsh. leaves, the extract exhibited a potent inhibitory effect on $\alpha$-glucosidase in vivo and in vitro and acertannin was isolated via assay-guided fractionation of the crude extract [22]. Wu et al. were studied the antibacterial activities of extracts prepared with 50\% ethanol from five Acer species (Acer platanoides L., Acer campestre L., Acer rubrum L., Acer saccharum Marsh. and Acer truncatum Bunge) against 24 standard bacteria strains. They showed more inhibitor activity against Gram-positive bacteria and were effective by a different mechanism from levofloxacin. They also inhibited $\beta$ ketoacyl-ACP reductase (FabG), which has an important role in bacterial fatty acid synthesis. Additionally, tannic acid and two maple leaf extracts, exhibited better inhibition on bacteria, showed time-dependent irreversible inhibition of FabG [23]. In another study on the antiprotease activity of certain medicinal plants from Slovakia, only the extracts of Acer platanoides and Rhus typhina L. showed urokinase inhibition activity [24]. The ash of the bark of Acer campestre subsp. campestre, is used to treat the inflamed wounds in traditional 
medicine, in Turkey (Catalca) [25]. The juice from gallnut on its leaves and branches is preferred for the treatment of eczema traditionally in Turkey (Kocaeli) [26].

In this study, the chemical composition profile by preliminary qualitative phytochemical analysis of various extracts obtained from the leaves and twigs of Acer campestre subsp. campestre (ACC), used traditionally in various inflammatory diseases especially hemorrhoids and rheumatism in Turkey, and the antioxidant activity, total phenolic content and antimicrobial activity of various extracts obtained from the leaves and twigs of ACC and also of the maple syrup and its subextracts were investigated. Additionally, the activities and total phenolic content of ACC extracts were compared with the activities of the maple syrup and its extract, for the aim to make a prediction about the possibility for usage in infectious diseases and about the anti-inflammatory activity of ACC.

\section{MATERIAL and METHODS}

\subsection{Plant Material}

The maple syrup was procured from the overseas market. The leaves and twigs of Acer campestre L. subsp. campestre were collected from Catalca - Istanbul (Turkey), in July 2017 and the voucher specimen has been deposited in the Herbarium of the Faculty of Pharmacy, Istanbul University (ISTE 115948).

\subsection{Preliminary Qualitative Phytochemical Analysis}

The infusions were prepared from $5 \mathrm{~g}$ of air-dried and powdered plant part with $100 \mathrm{~mL}$ boiled water in $30 \mathrm{~min}$. After cooling, the infusions were filtered. Following tests were performed with these filtrates for qualitative detection of phytochemicals e.g. flavonoids, anthracenes, saponins, tannins (catechic tannin and gallic tannin). In addition to these, the dried and powdered plant part was used for the tests alkaloids [27]. The results were expressed in the presence $(+)$ and absence $(-)$ of the phytochemicals.

\subsubsection{Test for flavonoids}

Over 5mL infusion, 5mL Shibata Reagent (conc. $\mathrm{HCl}+$ water+ethanol) and a piece of Magnesium were added and it has been observed whether orange, red or purple color has occurred (Shibata Reaction $=$ Cyanidin Reaction).

\subsubsection{Test for Anthracene Compounds}

Over $10 \mathrm{~mL}$ infusion, 5 drops concentrated $\mathrm{H}_{2} \mathrm{SO}_{4}$ was added. The mixture was warmed in boiling water for $15 \mathrm{~min}$. and extracted with $5 \mathrm{~mL}$ toluene after cooling. Over the toluene phase, $3 \mathrm{~mL} \mathrm{NH}_{3}$ solution (10\%) was added and it has been observed whether rose pink to red color has occurred.

\subsubsection{Test for Saponins}

$10 \mathrm{~mL}$ infusion was shaken vigorously in a graduated cylinder for $30 \mathrm{sec}$. and it has been observed after $15 \mathrm{~min}$. whether minimum $1 \mathrm{~cm}$ foam layer has occurred.

\subsubsection{Test for Tannins}

\subsubsection{Gelatin Test (for the General Determination of Tannins)}

Over $5 \mathrm{~mL}$ infusion, $2 \mathrm{~mL}$ Gelatin-salt Reagent (Gelatin solution (1\%) saturated with $\mathrm{NaCl}$ ) was added. It has been observed whether cream-beige precipitate has occurred.

\subsubsection{Separation of the Type of Tannins}

$1^{\text {st }}$ step - Ferric Chloride Test: Over $10 \mathrm{~mL}$ infusion, 3 drops $\mathrm{FeCl}_{3}(5 \%)$ was added. It has been observed whether blue-black colour (gallic tannin) or dark olive green (catechic tannin) has occurred. 
$\underline{2^{\text {nd }}}$ step - Stiasny Reaction (for the separation of tannin types): Over $10 \mathrm{~mL}$ infusion, $5 \mathrm{~mL}$ Stiasny Reagent (formol in water $(30 \%)+$ conc. $\mathrm{HCl}$ ) was added. The mixture was warmed in water $\left(80^{\circ} \mathrm{C}\right)$ for $30 \mathrm{~min}$. When the material contains catechic tannin, precipitates in potions appeared. After cooling of the mixture, it was filtered. $3 \mathrm{~mL}$ filtrate was saturated with sodium acetate. After adding of 3 drops diluted $\mathrm{FeCl}_{3}$ solution, it has been observed whether blue-black precipitate or colour has occurred.

\subsubsection{Test for Alkaloids}

$1 \mathrm{~g}$ of air-dried and powdered plant part was extracted with $10 \mathrm{~mL} \mathrm{H}_{2} \mathrm{SO}_{4}$ solution (3\%) in hot water. It was cooled and filtered. After adding $5 \mathrm{~mL} \mathrm{NH}_{3}$ solution (10\%), it was stirred with $10 \mathrm{~mL}$ ether. The layers were allowed to separate. The etheric phase was evaporated to dryness. The residue was dissolved in $10 \mathrm{~mL} \mathrm{H}_{2} \mathrm{SO}_{4}$ solution $(3 \%)$. The alkaloid control reactions were made on this solution in 3 portions.

1. After adding of the Mayer Reagent (mercuric chloride + potassium iodide + water), it has been observed whether milk-white precipitate has occurred.

2. After adding of the Bouchardat Reagent (iodine + potassium iodide + water), it has been observed whether dark red precipitate has occurred.

3. After adding of the Dragendorff Reagent (bismuth carbonate + potassium iodide + water), it has been observed whether orange-red precipitate has occurred.

\subsection{Preparation of the Plant Material for the Preliminary Analysis}

\subsubsection{Total Moisture Content (Loss on Drying)}

Air-dried and powdered plant part (weight: A) was put into a pre-dried and weighed (WAc1) crucible. The samples were dried in an oven at $100^{\circ} \mathrm{C}$ for 2 hours. It was cooled in desiccators and reweighed (WAc2). The percent loss of weight of air-dried sample was calculated by equation: $\%=($ WAc2-WAc1 $) \times 100 / \mathrm{A}$

\subsubsection{Total Ash Content}

Air-dried and powdered plant part (weight: A) was put into a pre-dried and weighed (Wc1) crucible. The sample was ignited gradually in an electrical muffle in $300^{\circ} \mathrm{C}$ for $15 \mathrm{~min}$ and after this $500^{\circ} \mathrm{C}$ for $15 \mathrm{~min}$. The process was allowed to cool by taking a break for a while. After dropping 1-2 drops of water, the temperature was gradually increased. When the temperature reached $800^{\circ} \mathrm{C}$ by gradually increasing, it was ignited in $800^{\circ} \mathrm{C}$ for $30 \mathrm{~min}$. It was cooled in desiccators and reweighed (Wc2). Total ash content was calculated as in equation: $\%$ $=(\mathrm{Wc} 2-\mathrm{Wc} 1) \times 100 / \mathrm{A}$

\subsection{Extraction and Preparation of Samples}

After dissolution of syrup in alcohol-water mixture, it was subjected to liquid-liquid partitioning sequentially with ethyl acetate (SEtOAc) and butanol $(\mathrm{SBuOH})$. The dried and powdered plant part was macerated with ethanol, separately with stirring for $24 \mathrm{~h}$ (Ac1) and 48 $\mathrm{h}$ (Ac2). Only the half of Ac1 was subjected to liquid-liquid partitioning sequentially with ethyl acetate (Ac1EtOAc), but the partition could not continue with butanol because of a phase separation problem. An infusion and a decoction were prepared separately from another portions as in its traditional use. The organic extracts were evaporated to dryness and the aqueous extracts were lyophilized. The extracts were stored at $\pm 4^{\circ} \mathrm{C}$ till further used.

\subsection{Antioxidant Assay and Determination of Total Phenolic Contents}

All samples were applied to the microplates by DPPH method and Folin-Ciocalteu reagent (FCR) method, as shown in Figure 1 and Table 1. 


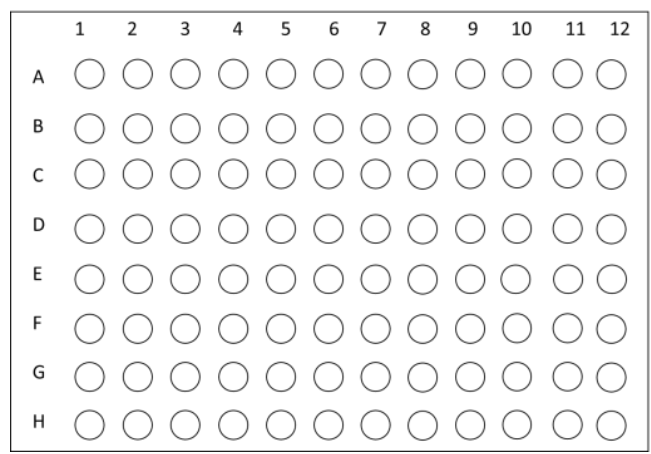

Figure 1. Microplate in antioxidant assay

Table 1. Application order in antioxidant assay by DPPH method

\begin{tabular}{cccccc}
\hline Wells & $\begin{array}{c}\text { References and } \\
\text { Samples }\end{array}$ & Wells & $\begin{array}{c}\text { References and } \\
\text { Samples }\end{array}$ & Wells & $\begin{array}{c}\text { References and } \\
\text { Samples }\end{array}$ \\
\hline A1-A3 & BHT $(46.3 \mu \mathrm{g} / \mathrm{mL})$ & A4-A6 & Decoction & A7-A9 & SEtOAc \\
B1-B3 & BHT $(92.5 \mu \mathrm{g} / \mathrm{mL})$ & B4-B6 & Infusion & B7-B9 & SBuOH \\
C1-C3 & BHT $(187.5 \mu \mathrm{g} / \mathrm{mL})$ & C4-C6 & Ac1 & C7-C9 & Syrup \\
D1-D3 & BHT $(375 \mu \mathrm{g} / \mathrm{mL})$ & D4-D6 & Ac2 & & \\
E1-E3 & BHT $(750 \mu \mathrm{g} / \mathrm{mL})$ & E4-E6 & Ac1EtOAc & & \\
F1-F3 & BHT $(1.5 \mathrm{mg} / \mathrm{mL})$ & & & & \\
G1-G3 & BHT $(3 \mathrm{mg} / \mathrm{mL})$ & & & & \\
\hline
\end{tabular}

\subsubsection{DPPH Radical Scavenging Activity}

The DPPH (2,2-diphenyl-1-picryl-hydrazil) radical scavenging activity of all samples were measured by the DPPH method described by Bardakci et al. [28]. $25 \mu \mathrm{L}$ of extracts $(5 \mathrm{mg} / \mathrm{mL})$ were individually mixed with $200 \mu \mathrm{L}$ of DPPH solution $(0.1 \mathrm{mM})$ freshly prepared in methanol. Following the incubation period in the dark at room temperature, the absorbance was measured against the reference using a micro plate reader at $517 \mathrm{~nm}$. Butylated hydroxytoluene (BHT) was preferred as reference substance.

DPPH radical-scavenging activity was calculated as follows:

DPPH radical scavenging activity $(\%)=\left[\left(\mathrm{Abs}_{\mathrm{control}}-\mathrm{Abs}_{\mathrm{sample}}\right) / \mathrm{Abs}_{\mathrm{control}}\right]^{* 100}$

$\mathrm{Abs}_{\text {control }}=$ the absorbance value of the control group

$\mathrm{Abs}_{\text {sample }}=$ the absorbance of the samples

\subsubsection{Determination of Total Phenolic Contents in Extract}

Total phenolic content of plant extracts was measured with slight modifications on previously described method by Singleton and Rossi [29]. $20 \mu \mathrm{L}$ of the extracts $(5 \mathrm{mg} / \mathrm{mL})$ were mixed with $100 \mu \mathrm{L}$ of Folin-Ciocalteu reagent [FCR; diluted with distilled water (9:1)] in basic medium $[\mathrm{pH} \sim 10 ; 300 \mu \mathrm{L}$ sodium carbonate solution (20\%)]. After a $30 \mathrm{~min}$. incubation period at $45{ }^{\circ} \mathrm{C}$, absorbance was read at $765 \mathrm{~nm}$. Gallic acid was used as a standard and a calibration curve was plotted in a concentration range of $50-500 \mathrm{mg} / \mathrm{L}$. All experiments were performed triplicate and total phenolic content was expressed as $\mathrm{mg}$ of gallic acid equivalents per $\mathrm{g}$ of the extract.

\subsection{Antimicrobial Assay}

In vitro antibacterial activities of samples were investigated against Gram positive bacteria (Staphylococcus aureus ATCC 29213, Staphylococcus epidermidis ATCC 12228 and 
Enterococcus faecalis ATCC 29212); Gram negative bacteria (Escherichia coli ATCC 25922, Klebsiella pneumoniae ATCC 4352 and Pseudomonas aeruginosa ATCC 27853) and also their antifungal activities against Candida albicans ATCC 10231. Minimum inhibitory concentrations (MICs) of compounds were determined by microbroth dilution technique as described by the Clinical and Laboratory Standards Institute (CLSI) [30,31].

For this purpose, serial two-fold dilutions of extracts ranging from $5000 \mu \mathrm{g} / \mathrm{mL}$ to 9.76 $\mu \mathrm{g} / \mathrm{mL}$ were prepared in Mueller-Hinton Broth (MHB) (Difco, Detroid, USA) for bacteria and RPMI-1640 (Sigma) medium for yeast. The inoculums were diluted in broth media to give a final concentration of $5 \times 10^{5} \mathrm{cfu} / \mathrm{mL}$ for bacteria and $0.5 \times 10^{3}$ to $2.5 \times 10^{3} \mathrm{cfu} / \mathrm{mL}$ for yeast in the test tray. The trays were incubated at $37^{\circ} \mathrm{C}$ for $18-24 \mathrm{~h}$. The MIC was defined as the lowest concentration of compound giving complete inhibition of visible growth. To verify the standardization of test procedure, Levofloxacin and Fluconazole were used as reference antibiotics for bacteria and yeast, respectively.

\section{RESULTS and DISCUSSION}

\subsection{Antimicrobial Assay}

The results of the preliminary qualitative phytochemical analysis are summarized in Table 2. Catechic tannin, saponins and flavonoids are determined in Acer campestre L. subsp. campestre leaves and twigs.

Table 2. The preliminary qualitative phytochemical analysis results to determine the contents of Acer campestre L. subsp. campestre leaves and twigs

\begin{tabular}{llc}
\hline Secondary metabolites & & Plant sample \\
\hline \multirow{2}{*}{ Alkaloids } & Bouchardat Reaction & - \\
\cline { 2 - 3 } & Dragendorff Reaction & - \\
\cline { 2 - 3 } & Mayer Reaction & - \\
\hline Anthracene analogs & & + \\
\hline Flavonoids & Gallic tannin & ++ \\
\cline { 2 - 3 } Saponins & Catechic tannin & ++ \\
\hline \multirow{2}{*}{ Tannins } & $\begin{array}{l}\text { ++ = higher amount of the secondary metabolite; }+ \text { = presence of the secondary metabolite; }- \text { - absence of the } \\
\text { secondary metabolite }\end{array}$
\end{tabular}

\subsection{Total Moisture (Loss on Drying) and Total Ash Contents}

The total moisture and total ash contents of the Acer campestre L. subsp. campestre leaves and twigs was found $7.82 \%$ and $5.31 \%$, respectively.

\subsection{Antioxidant Assay and Determination of Total Phenolic Contents}

The extracts Ac2 (91.2\%), Ac1EtOAc (91.1\%) and Ac1 (88.8\%) exhibited the higher radical scavenging activity than other samples, while the decoction and infusion had moderate activities. Beside of this, it was found that the syrup and its subextracts had more total phenolic contents than other extracts. The images of the microplates for DPPH method and FolinCiocalteu reagent (FCR) method, were shown in Figure 2 and Figure 3, respectively. The results were shown at Table 3. 


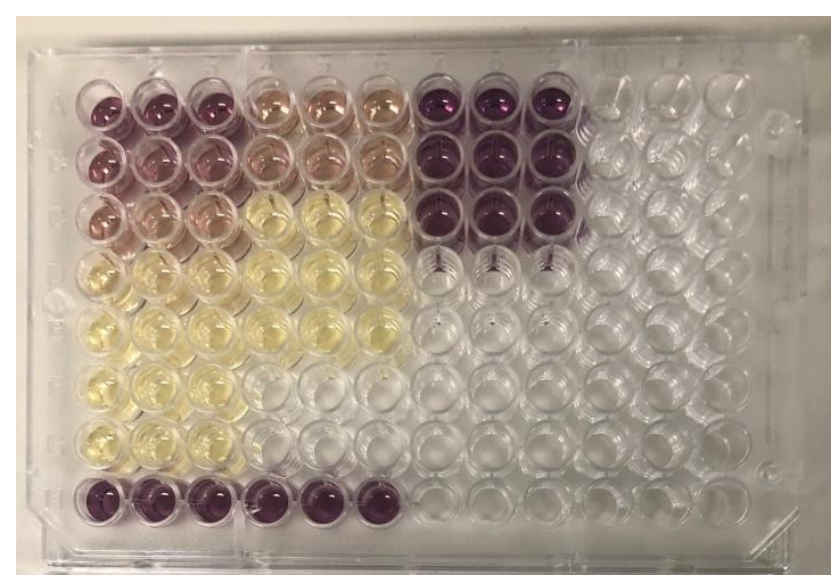

Figure 2. Microplate image in antioxidant assay by DPPH method

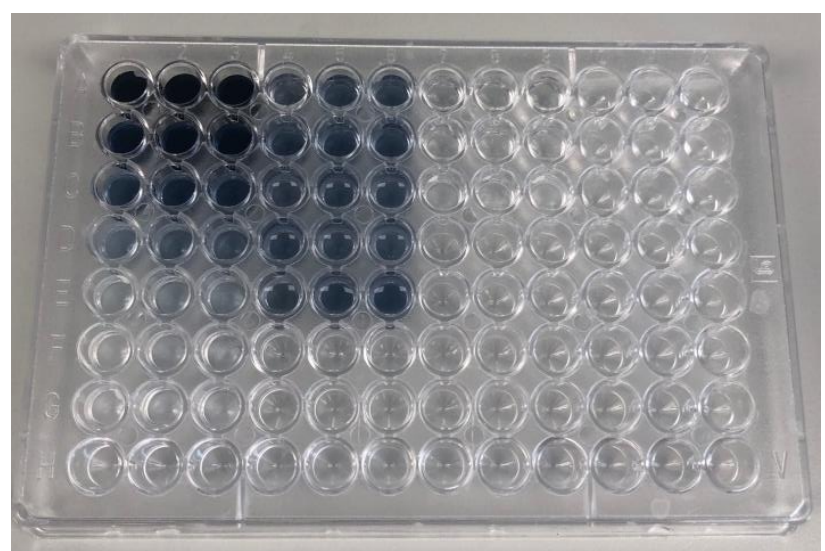

Figure 3. Microplate image for total phenolic contents by Folin-Ciocalteu reagent (FCR) method.

Table 3. The results of DPPH antioxidant activity assays and total phenolic content of the extracts $(5 \mathrm{mg} / \mathrm{mL})$ Acer campestre L. subsp. campestre leaves and twigs.

\begin{tabular}{lcc}
\hline Extracts & DPPH $(\%$ scavenging) & Total phenolic content $(\mathrm{mg}$ of GAE per g of extract) \\
\hline Decoction & 67.60268 & 70.19 \\
Infusion & 64.39584 & 78.86 \\
Ac1 & 88.79661 & 12.91 \\
Ac1EtOAc & 91.08663 & 6.72 \\
Ac2 & 91.17296 & 6.49 \\
Syrup & 1.549973 & 248.7 \\
SETOAc & 2.088558 & 247.25 \\
SBuOH & 2.043333 & 247.37 \\
BHT & 88.00 & - \\
\hline
\end{tabular}

These values are the means of three replicates. DPPH: 2,2-diphenyl-1-picrylhydrazyl; GAE: gallic acid equivalents

\subsection{Antimicrobial Assay}

Among tested samples, all samples except $\mathrm{SBuOH}$ had an antibacterial activity against $P$. aeruginosa while only SEtOAc and Ac2 showed an activity against E. coli. In addition, all samples except $\mathrm{SBuOH}$ and Ac1EtOAc exhibited antifungal activity against $C$. albicans. Especially the extract Ac1 and Ac2 were the most active samples against $C$. albicans. The results of in vitro antimicrobial activities of all samples were shown in Table 4. 
Table 4. In vitro antimicrobial activities of samples

\begin{tabular}{lccccccc}
\hline & \multicolumn{7}{c}{ MIC values $(\mu \mathrm{g} / \mathrm{mL})$} \\
\cline { 2 - 8 } Extracts & S.a & S.e & E.f & E.c & K.p & P.a & C.a \\
\hline Decoction & - & - & - & - & - & 1250 & 625 \\
Infusion & - & - & - & - & - & 1250 & 1250 \\
Ac1 & - & - & - & - & - & 625 & 78 \\
Ac1EtOAc & - & - & - & - & - & 1250 & - \\
Ac2 & - & - & - & 1250 & - & 625 & 156 \\
SETOAc & - & - & - & 1250 & - & 1250 & 312.5 \\
SBuOH & - & - & - & - & - & - & - \\
\hline
\end{tabular}

S.a: S.aureus ATCC 29213; S.e: S.epidermidis ATCC 12228; E.f: E.faecalis 29212; E.c: E.coli ATCC 25922; K.p: K.pneumoniae ATCC 4352; P.a: P.aeruginosa ATCC 27853; C.a: C.albicans ATCC 10231, -: no inhibition

Reactive oxygen radicals such as superoxide anion $\left(\mathrm{O}_{2}{ }^{*}\right)$, hydroxyl radicals $\left(\mathrm{OH}^{*}\right)$, singlet oxygen $\left({ }^{1} \mathrm{O}_{2}\right)$ and hydrogen peroxide $\left(\mathrm{H}_{2} \mathrm{O}_{2}\right)$ are known to play a major role in the development of oxidative stress. As a result, diseases such as cardiovascular diseases, inflammation, diabetes, degenerative diseases, cancer, anemia occur. In the literature, the relationship between antioxidant activity and anti-inflammatory activity has been revealed by studies in which plants' antioxidant and anti-inflammatory activities are investigated simultaneously [1-4]. As a result of this study, it was stated that there was a high correlation between these activities, and the plants rich in total phenolic content and flavonoids exhibited anti-inflammatory activity [1]. Oxygenated radicals are known to play a role in inflammation. In another study, antioxidant activities of 20 plants, known with their anti-inflammatory effects, were studied and the relationship between these activities was shown again [2]. There is a research in the literature that there is also a correlation between antioxidant and antimicrobial activities of plants [32]. With all these in mind, the maple syrup, the ethanol extracts of ACC prepared with different extraction method, and their subextracts were tested for their antioxidant and antimicrobial activities and total phenolic contents. All these results were examined comparatively and the samples with anti-inflammatory potential were evaluated. In parallel with the usage in the treatment of inflammatory wounds in traditional medicine and the relationship between antioxidant and anti-inflammatory activities, the expected antioxidant activity from the extracts of the species was determined. In fact, some extracts showed higher activity then the standard BHT, as in previous on some other Acer species. In a study on A. tegmentosum Maxim., the $70 \%$ ethanolic extract of its leaves exhibited more stronger activity than BHT even at the concentration of $0.1 \mathrm{mg} / \mathrm{mL}$ [33]. Also, Watanabe and Devkota determined that the antioxidant activity of $70 \%$ methanolic extract of Acer tataricum subsp. ginnala (Maxim.) Wesm. (syn. A. ginnala Maxim.var. aidzuense Franch.) leaves $\left(\mathrm{EC}_{50}: 7.0 \mu \mathrm{g} / \mathrm{mL}\right)$ had higher activity then the standard Trolox (EC50: $12.2 \mu \mathrm{g} / \mathrm{mL}$ ) [34]. Unlike these, the methanol extract elicited equivalent activity ( $\mathrm{IC}_{50}: 15 \mu \mathrm{g} / \mathrm{mL}$ ) to that of standards (BHA: $\mathrm{IC}_{50}: 14 \mu \mathrm{g} / \mathrm{mL} ; \alpha$-Tocopherol: $12 \mu \mathrm{g} / \mathrm{mL}$ ) in a investigation on the biological activities of A. tataricum subsp. ginnala (Maxim.) Wesm. (syn. A. ginnala Maxim.), while the water and hexane subextracts $(50.0 \mu \mathrm{g} / \mathrm{mL}$ and $46.3 \mu \mathrm{g} / \mathrm{mL}$, respectively) were less active than the standards [35]. Also, the alcohol extract of $A$. rubrum (antioxidant capacity $=3325 \pm 129$ ) showed higher activity and the alcohol extract of $A$. saccharum (antioxidant capacity $=968 \pm 155$ ) exhibited less activity than the commercial standardized French maritime pine bark extract Oligopin ${ }^{\circledR}($ antioxidant capacity $=1930 \pm 101)$ [36]. In another study, the phenolic contents and antioxidant activities of the methanol extracts prepared from the leaves and branches of $A$. campestre collected in different locations were 
evaluated comparatively. Their antioxidant activity were found more than BHT or similar to it (IC50 values of BHT: $27.80 \mu \mathrm{g} / \mathrm{mL}$; of leaves collected in Guerrouche and Ain El Kebira: 16.67 $\pm 4.26 \mu \mathrm{g} / \mathrm{mL}$ and $28.33 \pm 7.26 \mu \mathrm{g} / \mathrm{mL}$, respectively) [37]. In this present study, the alcohol extracts showed higher activity than BHT; but the ethyl acetate subextract also exhibited high activity unlike previous studies (DPPH radical scavenging activity $(\%)$ at the concentration of $5 \mathrm{mg} / \mathrm{mL}=$ Ac1: $88.79661 \%$; Ac1EtOAc: $91.08663 \%$; Ac2: 91.17296\%; BHT: $88.00 \%)$. It was also noteworthy that despite the high phenolic content, syrup samples showed lower activity compared to alcohol extracts. Alcohol macerates and their subextracts exhibited the highest radical scavenging effect. Beside of this, the syrup and their subextracts were found to have the highest phenolic content. Having parallel results in phenolic content and antioxidant activity tests have become an expected result in the literature. Extracts with high phenolic content also exhibit high antioxidant activity; however, this may not apply to Acer species. While the extract of A. tegmentosum Maxim. leaves was more active than standard, its total phenolic content was only $116.35 \pm 1.4 \mathrm{mg} \mathrm{GAE} / \mathrm{g}$ [33]. Although alcohol extract of $A$. rubrum was found to be twice times more active than Oligopin ${ }^{\circledR}$, its total phenolic content was determined $378.6 \pm 1.1 \mathrm{mg}$ $\mathrm{GAE} / \mathrm{g}$, the total phenolic content of the alcohol extract of $A$. saccharum with less activity was $211.7 \pm 9.6 \mathrm{mg} \mathrm{GAE} / \mathrm{g}$ [36]. In another study, the water extracts of A. rubrum bark, exhibited approximately 2-3 times less activity than Oligopin ${ }^{\circledR}$, had similar total phenolic contents to this standard (extracts: 528.8 and $540.3 \mathrm{mg} \mathrm{GAE} / \mathrm{g}$; Oligopin ${ }^{\circledR}: 572.9 \mathrm{mg}$ GAE/g); but the A. saccharum water extract with the half amount of total phenolic compounds (298.6 mg GAE/g) showed higher effect than standard [38]. In spite of these, a correlation between antioxidant activity and total phenolic content was determined in a study on the A. campestre by Atroune et al. [37]. On the other hand, this correlation did not detected in this present study

Considering that the DPPH method gives information about the radical scavenging activity of polar compounds, the fact that the extracts prepared with alcohol show very high antioxidant activity despite their low phenolic content suggests that polar phenolic compounds in these samples may be highly potent antioxidant agents. However, the extracts prepared with water showed less activity than those prepared with alcohol; this means that polar phenolic compounds only in alcohol extracts have higher antioxidant potential. Having high antioxidant activity also brings to mind the high anti-inflammatory potential as mentioned above. However, other antioxidant methods are needed to make a full assessment upon the low antioxidant activity of these samples At the same time, the secondary metabolite group, tannins, saponins and flavonoids, were found to be present in the plant in preliminary qualitative phytochemical analysis. In other studies on Acer species, the fact that different tannin compounds are responsible for many different activities $[35,39,40]$. The presence of such tannin compounds in this species suggested that the tannins content of ACC extracts should be examined in future studies.

Moskalenko investigated 8 Acer species [A. barbinerve Maxim. ex. Miq., A. tataricum subsp. ginnala (Maxim.) Wesm. (syn. A. ginnala Maxim.), A. mandshuricum Maxim., A. pictum Thunb. (syn. A. mono Maxim.), A. negundo L., A. pseudosieboldianum (Pax.) Kom., A. Tegmentosum Maxim., A. caudatum subsp. ukurundense (Trautv. \& C.A.Mey.) E.Murray (syn. A. ukurunduense Trautv. \& C.A. Mey)] for their antibacterial activity against Staphylococcus aureus, Escherichia coli, Shigella sonnei, S. flexneri, Bacillus subtilis and Mycobacterium smegmatis. The ethanol (70\%) extracts of A. tataricum subsp. ginnala (syn. A. ginnala) had the highest activity against all bacteria among the Acer extracts, while the ethanol extract of $A$. pictum (syn. A. mono)exhibited no activity [41]. In a study on the antibacterial effect mechanism of $A$. truncatum, the $50 \%$ ethanolic extract was found to be effective on $S$. aureus, S. epidermidis and E. coli (MIC values are $0.5 \mathrm{mg} / \mathrm{mL}, 0.25 \mathrm{mg} / \mathrm{mL}, 0.5->0.5 \mathrm{mg} / \mathrm{mL}$, respectively), and its ethyl acetate subextract showed an effect against all bacteria ( $S$. aureus, S. epidermidis, E. coli and Pseudomonas aeruginosa) with the MIC values of $0.25 \mathrm{mg} / \mathrm{mL}$, 
$0.125 \mathrm{mg} / \mathrm{mL}, 0.25 \mathrm{mg} / \mathrm{mL}$ and $0.25 \mathrm{mg} / \mathrm{mL}$, respectively [42]. The methanol extract, prepared from the stem of Acer pentapomicum Stewart ex Brandis, and its hexane, chloroform, ethyl acetate, butanol and aqeous subextracts were tested for their antibacterial effects by disc diffusion susceptibility assay, and showed their effects dose-dependent. All samples had more or less an activity against E. coli and Klebsiella pneumoniae. The methanol extract and its ethyl acetate and butanol subextracts were active against $S$. aureus at all concentrations, while chloroform subextract had no effect [43]. In an investigation on the inhibitory effects on bacterial growth of the ethanolic (50\%) extracts from leaves of 5 Acer species (A. platanoides, A. campestre, A. rubrum, A. saccharum and A. truncatum), the A. campestre extract elicited a good activity against all studied microorganisms. It had an effect against $S$. aureus, $S$. epidermidis, Enterococcus spp., E. coli, K. pneumoniae and $P$. aeruginosa strains at the concentration of $1 \mathrm{mg} / \mathrm{mL}, 1 \mathrm{mg} / \mathrm{mL}, 4 \mathrm{mg} / \mathrm{mL}, 4 \mathrm{mg} / \mathrm{mL}, 8 \mathrm{mg} / \mathrm{mL}$ and $2 \mathrm{mg} / \mathrm{mL}$, respectively [23]. In this present study, an activity occured only against $E$. coli and $P$. aeruginosa among studied bacteria, but the effective concentrations were detected better than in previous study. These antimicrobial test results were obtained as like as the antioxidant test results. Both alcohol extracts showed high antimicrobial activity among other samples, especially against $C$. albicans. The butanol subextract of syrup showed no effect against any microorganism, while the alcohol extract obtained by 48-hour maceration and ethyl acetate subextract of syrup had an antimicrobial effect on three microorganisms ( $E$. coli, $P$. aeruginosa and $C$. albicans). It is noteworthy that both alcohol extracts show higher antifungal activity $(78 \mu \mathrm{g} / \mathrm{mL}$ and 156 $\mu \mathrm{g} / \mathrm{mL}$ ) against $C$. albicans than other extracts and also important that the alcohol extract obtained by 24-hour maceration has higher activity than the alcohol extract obtained by 48 hour maceration. In the light of this, it can be concluded that the compounds with lower or no activity could be extracted with the exposure of alcohol for a long time. It appears that the total phenolic content is not a criterion for antimicrobial activity. As a matter of fact, while the MIC value of alcohol extract obtained by 24-hour maceration was the highest, its phenolic content was quite the fewer than other extracts. It was also concluded that most of the compounds that play a role in the activity of this extract were not phenolic compounds.

\section{CONCLUSION}

The knowledge on Acer campestre is quite few because of the limited investigations in literature. Promising results have been obtained in both antioxidant and antimicrobial tests. Similar to previous studies, parallelism was observed in both activity test results. The high antioxidant results suggest a good potential of this species for anti-inflammatory activity. It is interesting that the plant shows higher activity than the syrup content in the market. It is thought that a significant contribution to the use of the plant in treatment of various inflammation disorders, will be made when working in this direction and studying the role of tannins in activities of the plant.

\section{Acknowledgements}

The authors declare that, this study was a graduation thesis of Yavuz Selim Bal (Advisor: Burcu Sen-Utsukarci).

\section{Declaration of Conflicting Interests and Ethics}

The authors declare no conflict of interest. This research study complies with research publishing ethics. The scientific and legal responsibility for manuscripts published in IJSM belongs to the author(s).

Orcid

Burcu Sen-Utsukarci (D) https://orcid.org/0000-0002-2720-9686

Yavuz Selim Bal (D) https://orcid.org/0000-0002-5226-5081 
Bahar Gurdal (D) https://orcid.org/0000-0003-4009-100X

Hilal Bardakci (DiD https://orcid.org/0000-0001-8799-6565

Fatima Nur Yilmaz (iD https://orcid.org/0000-0001-8442-8538

Sibel Dosler (iD https://orcid.org/0000-0001-5223-4755

\section{REFERENCES}

[1]. Ravipati, A.S., Zhang, L., Koyyalamudi, S.R., Jeong, S.C., Reddy, N., Bartlett, J., Satyanarayanan, M. (2012). Antioxidant and anti-inflammatory activities of selected Chinese medicinal plants and their relation with antioxidant content. BMC Complement. Altern. Med., 12, Article number: 173. https://doi.org/10.1186/1472-6882-12-173

[2]. Schinella, G.R., Tournier, H.A., Prieto, J.M. (2002). Antioxidant activity of antiinflammatory plant extracts. Life Sciences, 70, 1023-1033. https://doi.org/10.1016/S00243205(01)01482-5

[3]. Zhang, L., Ravipati, A.S., Koyyalamudi, S.R., Jeong, S.C., Reddy, N., Smith, P.T., Bartlett, J., Shanmugam, K., Münch, D.G., Wu, M.J. (2011). Antioxidant and Anti-inflammatory Activities of Selected Medicinal Plants Containing Phenolic and Flavonoid compounds. J. Agric. Food Chem., 59, 12361-12367. https://doi.org/10.1021/jf203146e

[4]. Talhouk, R., Karam, C., Fostok, S., El-Jouni, W., Barbour, E. (2007). Anti-inflammatory bioactivities in plant extracts. J. Med. Food, 10, 1 10. https://doi.org/10.1089/jmf.2005.0 55

[5]. Zhang, Y., Yuan, T., Li, L., Nahar, P., Slitt, A., Seeram, N.P. (2014). Chemical compositional, biological, and safety studies of a novel maple syrup derived extract for nutraceutical applications. J. Agric. Food Chem., 62, 6687 6698. https://doi.org/10.1021 /jf501924y

[6]. Perkins, T.D., van den Berg, A.K. (2009). Maple syrup-production, composition, chemistry, and sensory characteristics. In Advances in Food and Nutrition Research; Taylor, S.L. Ed.; Academic Press, Elsevier, USA, 2009, Volume 56, pp. 101-143. ISBN: 978-0-12-374439-5

[7]. Storz, G., Darvill, A.G., Albersheim, P. (1986). Characterization of polysaccharides isolated from maple syrup. Phytochemistry, 25, 437-441, https://doi.org/10.1016/S00319422(00)85497-7

[8]. Ball, D. W. (2007). The chemical composition of maple syrup. J. Chem. Educ., 84, 16471650. https://doi.org/10.1021/ed084p1647

[9]. Li, L., Seeram, N.P. (2010). Maple syrup phytochemicals include lignans, coumarins, a stilbene and other previously unreported antioxidant phenolic compounds. J. Agric. Food Chem., 58, 11673-11679. https://doi.org/10.1021/jf1033398

[10]. Li, L., Seeram, N.P. (2011). Further investigation into maple syrup yields three new lignans, a new phenylpropanoid, and twenty-six other phytochemicals. J. Agric. Food Chem., 59, 7708-7716. https://doi.org/10.1021/jf2011613

[11]. Li, L., Seeram, N.P. (2011). Quebecol, a novel phenolic compound isolated from Canadian maple syrup. J. Funct. Foods, 3, 125-128. https://doi.org/10.1016/j.jff.2011.02.004

[12]. Yuan, T., Li, L., Zhang, Y., Seeram, N.P. (2013). Pasteurized and sterilized maple sap as functional beverages: Chemical composition and antioxidant activities. J. Funct. Foods, 5, 1582-1590. https://doi.org/10.1016/j.jff.2013.06.009

[13]. Kermasha, S., Goetghebeur, M., Dumont, J. (1995). Determination of phenolic compound profiles in maple products by high performance liquid chromatography. J. Agric. Food Chem., 43, 708-716. https://doi.org/10.1021/jf00051a028

[14]. Abou-Zaid, M.M., Nozzolillo, C., Tonon, A., Coppens, M., Lombardo, A.D.A. (2008). High performance liquid chromatography characterization and identification of 
antioxidant polyphenols in maple syrup. Pharm. Biol., 46, 117-125. https://doi.org/10.1080/13880200701735031

[15]. González-Sarrías, A., Li, L., Seeram, N. P. (2012). Effects of maple (Acer) plant part extracts on proliferation, apoptosis and cell cycle arrest of human tumorigenic and nontumorigenic colon cells. Phytother. Res., 26, 995-1002. https://doi.org/10.1002/ptr.3677

[16]. Legault, J., Girard-Lalancette, K., Grenon, C., Dussault, C., Pichette, A. (2010). Antioxidant activity, inhibition of nitric oxide overproduction, and in vitro antiproliferative effect of maple sap and syrup from Acer saccharum. J. Med. Food, 13, 460-468. https://doi.org/10.1089/jmf.2009.0029

[17]. Nahar, P.P., Driscoll, M. V., Li, L., Slitt, A. L., Seeram, N.P. (2014). Phenolic mediated anti-inflammatory properties of a maple syrup extract in RAW 264.7 murine macrophages. J. Funct. Foods, 6, 126-136. https://doi.org/10.1016/j.jff.2013.09.026

[18]. Watanabe, Y., Kamei, A., Shinozaki, F., Ishijima, T., Iida, K., Nakai, Y., Arai, S., Abe, K. (2011). Ingested maple syrup evokes a possible liverprotecting effect-physiologic and genomic investigations with rats. Biosci. Biotechnol. Biochem., 75, 2408-2410. https://d oi.org/10.1271/bbb.110532

[19]. Nagai, N., Ito, Y., Taga, A. (2013). Comparison of the enhancement of plasma glucose levels in type 2 diabetes Otsuka Long-Evans Tokushima fatty rats by oral administration of sucrose or maple syrup. J. Oleo Sci., 62, 737-743. https://doi.org/10.5650/jos.62.737

[20]. Thériault, M., Caillet, S., Kermasha, S., Lacroix, M. (2006). Antioxidant, antiradical and antimutagenic activities of phenolic compounds present in maple products. Food Chem., 98, 490-501. https://doi.org/10.1016/j.foodchem.2005.05.079

[21]. González-Sarrías, A., Yuan, T., Seeram, N.P. (2012). Cytotoxicity and structure activity relationship studies of maplexins A-I, gallotannins from red maple (Acer rubrum). Food Chem. Toxicol., 50, 1369-1376. https://doi.org/10.1016/j.fct.2012.02.031

[22]. Honma, A., Koyama, T., Yazawa, K. (2010). Anti-hyperglycemic effects of sugar maple Acer saccharum and its constituent acertannin. Food Chem., 123, 390394. https://doi.org/10.1016/j.foodchem.2010.04.052

[23]. Wu, D., Wu, X.D., You, X.-F., Ma, X.-F., Tian, W.-X.. (2010). Inhibitory Effects on Bacterial Growth and beta-Ketoacyl-ACP Reductase by Different Species of Maple Leaf Extracts and Tannic Acid. Phytother. Res., 24, S35-S41. https://doi.org/10.1002/ptr.2873

[24]. Jedinak, A., Valachova, M., Maliar, T., Sturdik, E. (2010). Antiprotease activity of selected Slovak medicinal plants. Pharmazie, 65, 137-140. https://doi.org/10.1691/ph.20 10.9668

[25]. Ecevit Genc G., Ozhatay N. (2006). An ethnobotanical study in Catalca (European part of Istanbul) II. Turk. J. Pharm. Sci., 3, 73-89.

[26]. Tuzlac1, E. (2016). Turkiye Bitkileri Geleneksel Ilac Rehberi; Istanbul Medikal Saglik ve Yayincilik, Istanbul, Turkey, pp. 630-631. ISBN: 9786054949717

[27]. Baytop, B. (1980). Farmakognozi, Volume I, 3. Edition; Istanbul Universitesi Yayinlari, Baha Matbaas1, Istanbul, Turkey, pp. 206-207.

[28]. Bardakci, H., Celep, E., Kurt-Celep, I., Deniz, I., Sen-Utsukarci, B., Akaydin, G. (2019). A comparative investigation on phenolic composition, antioxidant and antimicrobial potentials of Salvia heldreichiana Boiss. ex Bentham extracts. S. Afr. J. Bot., 125, 72-80. https://doi.org/10.1016/j.sajb.2019.07.010

[29]. Singleton, V.L., Rossi Jr., J.A. (1965). Colorimetry of total phenolics with phosphomolibdic-phosphotungtic acid reagents. Am. J. Enol. and Vitic., 16, 144-158.

[30]. Clinical and Laboratory Standards Institute (CLSI), (2000). Reference Method for Broth Dilution Antifungal Susceptibility Testing of Yeasts; Approved Standard M27-A NCCLS, Wayne, Pennsylvania. 
[31]. Clinical and Laboratory Standards Institute (CLSI), (2012). Methods for dilution antimicrobial susceptibility tests for bacteria that grow aerobically: Approved Standard, Ninth edition, M7-A9. Wayne, Pennsylvania.

[32]. de Freitas Araújo, M.G., Hilário, F., Vilegas, W., Dos Santos, L.C., Brunetti, I.L., Sotomayor, C.E., Bauab, T.M. (2012). Correlation among antioxidant, antimicrobial, hemolytic, and antiproliferative properties of Leiothrix spiralis leaves extract. Int. J. Mol. Sci., 13, 9260-9277. https://doi.org/10.3390/ijms13079260

[33]. Park, S.J., Shin E.H., Kim, D.H., Rha, Y.-A. (2016). Nutrition components and physicochemical properties of Acer termentosum Maxim. leaf. Culi. Sci. \& Hos. Res., 22, 27-38. https://doi.org/10.20878/cshr.2016.22.8.003

[34]. Watanabe, M., Devkota, H.P. (2017). Antioxidant phenolic constituents from the leaves of Acer ginnala var. aidzuense. Journal of Natural Remedies, 17, 9-12. https://doi.org/10.18311/jnr/2017/15632

[35]. Choi, Y.-H., Han S.S., Lee, H.O, Baek, S.H. (2005). Biological activity of bioactive components from Acer ginnala Max. Bull. Korean Chem. Soc., 26, 1450-1452. https://doi.org/10.5012/bkcs.2005.26.9.1450

[36]. Meda, N.R., Suwal, S., Rott, M., Poubelle, P.E., Stevanovic, T. (2016). Investigation of extracts from red and sugar maple buds as potential sources of antioxidant phytochemicals. Current Topics in Phytochemistry, 13, 69-78.

[37]. Atroune, F., Chaker, S., Djebbar, R., Dahmani-Megrerouche, M. (2019). Comparative evaluation of phenolics content and antioxidant activity of leaves and branches of field maple (Acer campestre) from two populations of Northeastern Algeria. Analele Universităţii din Oradea, Fascicula Biologie, 26, 7-13.

[38]. Geoffroy, T.R., Fortin, Y., Stevanovic, T. (2017). Hot-water extraction optimization of sugar maple (Acer saccharum Marsh.) and red maple (Acer rubrum L.) bark applying principal component analysis. J. Wood Chem. Technol., 37, 261-272. https://doi.org/10.1080/02773813.2017.1279631

[39]. Park, K.H., Yoon, K.H., Yin, J., Le, T.T., Ahn, H.S., Yoon, S.H., Lee, M.W. (2017). Antioxidative and anti-inflammatory activities of galloyl derivatives and antidiabetic activities of Acer ginnala. Evid.-Based Complementary Altern. Med., Article ID 6945912, 8 pages. https://doi.org/10.1155/2017/6945912

[40]. Lee, C.S., Jang, E.-R., Kim, Y.J., Seo, S.J., Choi, S.E., Lee, M.W. (2011). Polyphenol acertannin prevents TRAIL-induced apoptosis in human keratinocytes by suppressing apoptosis-related protein activation. Chem.-Biol. Interact., 189, 52-59. https://doi.org/10.1016/j.cbi.2010.10.009

[41]. Moskalenko, S.A. (1986). Preliminary screening of far-eastern ethnomedicinal plants for antibacterial activity. J. Ethnopharmacol., 15,231-259. https://doi.org/10.1016/03788741(86)90163-7

[42]. Zhang, F., Luo, S.Y., Ye, Y.B., Zhao, W.H., Sun, X.G., Wang, Z.Q., Li, R., Sun, Y.H., Tian, W.X., Zhang, Y.X. (2008). The antibacterial efficacy of an aceraceous plant [shantung maple (Acer truncatum Bunge)] may be related to inhibition of bacterial betaoxoacyl-acyl carrier protein reductase (FabG). Biotechnol. Appl. Biochem., 51, 73-78. https://doi.org/10.1042/BA20070255

[43]. Khan, S., Bakht, J., Shafi M. (2018). Antinociceptive, antimicrobial potential and phytochemical screening of different solvent extracted samples from the stem of Acer pentapomicum. Pak. J. Pharm. Sci., 31, 1457-1461. 